\title{
Perceived Organizational Politics, Support and Workplace Incivility of Supervisor as Predictors of Turnover Intention
}

\section{Emenike Samuel Ugwu1, Chiedozie Okechukwu Okafor ${ }^{2}$, Ike Ernest Onyishi ${ }^{3}$, Ani Casimir ${ }^{4}$, Ejiofor Chukwuemeka Chinedu ${ }^{5}$}

${ }^{1}$ Code of Conduct Tribunal, Enugu Zonal Office, Enugu, Nigeria

${ }^{2}$ Department of Psychology, Federal University, Ndufu-Alike, Ikwo, Nigeria

${ }^{3}$ Department of Psychology, University of Nigeria, Nsukka, Nigeria

${ }^{4}$ Department of Philosophy, University of Nigeria, Nsukka, Nigeria

${ }^{5}$ Department of Political Science, University of Nigeria, Nsukka, Nigeria

Email: *casimir.ani@unn.edu.ng, chukwuemeka.ejiofor@unn.edu.ng

How to cite this paper: Ugwu, E. S., Okafor, C. O., Onyishi, I. E., Casimir, A., \& Chinedu, E. C. (2018). Perceived Organizational Politics, Support and Workplace Incivility of Supervisor as Predictors of Turnover Intention. Open Journal of Political Science, 8, 547-560.

https://doi.org/10.4236/ojps.2018.84034

Received: August 28, 2018

Accepted: October 28, 2018

Published: October 31, 2018

Copyright $(0) 2018$ by authors and Scientific Research Publishing Inc. This work is licensed under the Creative Commons Attribution International License (CC BY 4.0).

http://creativecommons.org/licenses/by/4.0/

\begin{abstract}
The study examined perceived organizational politics, support and workplace incivility of supervisor as predictors of employees' intention to quit. The results of the regression analyses revealed that perceived organizational politics significantly predicted turnover intention $(\beta=.41, p<.001)$. Perceived politics accounted for $46.8 \%$ of the variance in turnover intention, above and beyond the control variables. Perceived organizational support was also found to be negatively related to turnover intention $(\beta=-.69, p<.001)$, and accounted for additional $31 \%$ of the variance in turnover intention. The results of the analyses equally indicated that workplace incivility significantly predicted turnover intention among employees $(\beta=.25, p<.001)$. And explained additional $3 \%$ of the variance in turnover intention above and beyond the control variables, perceived organizational politics, and perceived organizational support. These results were discussed based on existing theories and on the Nigerian socio-economic realities.
\end{abstract}

\section{Keywords}

Organizational Politics, Social Support, Work-Place Incivility, Employee, Turnover

\section{Introduction}

One of the critical challenges for organisations in today's dynamic and turbulent environment is to retain capable workforce for the maintenance and improve- 
ment of firm's competitive edge. Staff turnover is a serious issue in the field of human resource management. Its impact has received considerable attention by senior management, human resources professionals, and industrial psychologists. It has proven to be one of the most costly and seemingly intractable human resource challenges confronting organisations. Reducing employee turnover through retention practices is an area of great interest to organisational psychologists, organisations and employers who depend on a highly skilled workforce.

More so, in an organisation, politics has been shown by some researches (e.g. Harris, Andrews, \& Kacmar, 2007; Bozeman, Perrwere, Hochwarter, \& Brymer, 2001) to have inhibited maximum productivity, reduced job satisfaction and therefore increase the intention to quit. General political behaviour includes act in self-serving manner to achieving their individual goals (Kacmar \& Carlson, 1997). Thus perception of politics was always influencing individual reward structure and when employees work in a political environment, they may not have confidence that their behaviour will contribute to organisational reward structure (Cropanzano et. al., 1997). Pfeffer (1992) defined organisational politics as a general term that indicates power relations and influence tactics in workplace. Due to this political nature, the concept of organisational politics has received an increasing attention in management literature. Besides its practical implications, one of the reasons that consider politics and political behaviour in organisations as a promising field for theoretical inquiry is the general belief that views this phenomenon as one of the existing obstacles to the optimum performance of organisations (Kacmar \& Baron, 1999; Vigoda, 2000). On their own point of view, Kacmar, Bozeman, Carlson, \& Anthony (1999) opined that organisational politics involves actions by individuals, which are directed toward the goal of furthering their own self-interests without regard for the well-being of other or their organisation.

Perceived organisational support may lead directly to withdrawal cognitions and turnover. However, many turnover models suggest that organisational commitment and job satisfaction mediate relationships with withdrawal (e.g., Hom \& Griffeth, 1995). Employees see their employment as a reciprocal exchange relationship that reflects relative dependence and extends beyond a formal contract (Eisenberger, Armeli, Rexwinkel, Lynch, \& Rhoades, 2001). Research suggests that employees that benefit from the organisation's support will increasingly feel a sense of praise, support or approval from their organisation (Aselage \& Eisenberger, 2003). In other words, employees must gain this sense of support prior to their reciprocation of supportive human resource practices. Specifically, research has indicated that individuals who perceive that their organisation supports them are more likely to be satisfied with their job (Allen, Shore, \& Griffeth, 2003).

Although perceived organisational support is related to a variety of important work-related attitudes and outcomes, two issues requiring further attention are the relationship between perceived organisational support and voluntary turno- 
ver, and the factors leading to the development of perceived organisational support (Shore \& Shore, 1995; Shore \& Tetrick, 1991). Dimensions of perceived organisational support have been established as follows: role clearity (Eisenberger, Rhoades, \& Cameron, 1999; Zapf, Knorz, \& Kulla, 1996), job information, participation in decision-making (Allen, shore, \& Griffeth, 2003), support from co-workers (Djurkovic, McCormick, \& Casimir, 2004), supervisory support (Settoon, Bennett, \& Liden, 1996), which leads to increased job satisfaction (Eisenberger, Cummings, Armeli, \& Lynch, 1997), performance (Shanock \& Eisenberger, 2006) commitment (Hochwarter, Kacmar, Perrewe, \& Johnson, 2003) and reduced turnover (Allen, shore, \& Griffeth, 2003; Rhoades \& Eisenberger, 2002).

Organisational support theory (OST: Eisenberger, Huntington, Huntington, \& Sowa, 1986; Rhoades \& Eisenberger, 2002; Shore \& Shore, 1995) holds that in order to meet socio emotional needs and to assess the benefits of increased work effort, employees form a general perception concerning the extent to which the organisation values their contributions and cares about their well-being. Such perceived organisational support would increase employees' felt obligation to help the organisation reach its objectives, their affective commitment to the organisation and their expectation that improved performance would be rewarded. Behavioural outcomes of perceived organisational support would include increases in in-role and extra-role performance and decreases in stress and withdrawal behaviours such as absenteeism and turnover. Blau (1964) in his social exchange theory held that individuals consider potential reward and risks of social relationships and that all human relationships are shaped by using a subjective reward-cost analysis and the comparison of alternatives. He maintained that someone who gives much will expect to get at least the same amount back from others and in return, persons that receive a lot from others will be under pressure to give much back to them. Hui, Teo, \& Lee (2007) examined both perceived organisational support and turnover intention and found perceived organizational support was negatively related to thoughts of quitting the organizational. This finding also supported that of Kinnunen, Feldt, \& Makikangas (2008), who found that perceived organizational politics was negatively related to likelihood of leaving an organization and the frequency of thoughts about quitting the organization. However, Lew (2009) found that perceived organizational support has an insignificant direct effect on employees' turnover intention.

Moreover, incivility corrodes organisational culture and that employees who are on the receiving end will respond in ways that are costly to their organisations (Pearson \& Porath, 2005). Andersson \& Pearson (1999) defined workplace incivility as low intensity deviant behaviour that violates workplace norms for mutual respect and may or may not be intended to harm the target. Low intensity connotes verbal rather than physical, passive rather than active, and indirect rather than direct (Baron \& Neuman, 1996). Increasing numbers of researchers are paying attention to the causes and consequences of workplace incivility, with 
Baron \& Neuman's (1998) work serving as a classic study. Due to both the current interest and the practical limitations of conducting field research in the area of management, the majority of works related to workplace incivility are theoretical. Workplace incivility on its own has been a pervasive construct that has kept decreasing the moral and motivation of employees. Similarly, Shim \& Chang (2011) found positive relationships between workplace incivility of supervisor and intention to quit the organization.

Should we expect perceived organisational support to affect turnover? Based on social exchange theory, because feelings of obligation to support are expected to be created, we might expect high perceived organisational goals, to lower turnover. Eisenberger and coworkers (Eisenberger et al., 1986, 1990) argued that individual who perceives greater support from their employing organisation would be more likely to feel obligated to "repay" the organisation irrespective of perceived incivility. One way for an individual to repay the organisation is through continued participation. Eisenberger et al. (1990) argued that perceptions of support would encourage the adoption of organisational membership as an important part of an employee's self-identity. Thus, individuals perceiving greater support would be less likely to seek alternate employment or to leave the organisation. Such arguments are conceptually consistent with an inducements-contributions framework of voluntary turnover (March \& Simon, 1958) that serves as the foundations of much of contemporary turnover theory. However, the present researchers argue that this may not explain the job immobility of a typical Nigerian worker in the current job scarcity saga. To the extent that no study, to the best of our knowledge, has examined organizational politics, organizational support and perceived incivility as they predict intention to quit, this study is set to:

1) investigate whether perceived orgnaisational politics will significantly predict turnover intention;

2) ascertain if perceived organisational support will significantly predict turnover intention, and

3) investigate whether supervisor's incivility will significantly predict turnover intention.

The following hypotheses were tested:

Hypothesis 1: Perceived organisational politics will not significantly predict turnover intention.

Hypothesis 2: Perceived organisational support will be negatively related to turnover intention.

Hypothesis 3: Supervisor's incivility will not significantly predict turnover intention.

\section{Method}

\subsection{Participants}

Two hundred and twenty nine (229) employees participated in the study. These 
participants were selected from five (5) commercial banks in Nsukka urban and five (5) commercial banks in Enugu metropolis. These banks included: FCMB, First bank, Eco bank, Access bank, Diamond bank, UBA, Fidelity bank, Key stone, GTB, and Zenith bank. The participants were between the ages of 25 and 55 years, and a mean age of 40 years. They also had a minimum of OND certificate. The choice of study areas is based on three reasons which include: The population density in the banking sector, resulting from recent lay-off. Secondly, some banks have already been used for the pilot study and finally because of proximity.

\subsection{Instruments}

Four scales were used for the study and they included Turnover Intention Scale, Perceived Organisational Politics Scale; Survey of Perceived Organisational Support and Abusive Supervision Scale.

\subsection{Turnover Intention}

O’Driscoll \& Beehr's (1994) Turnover Intention Scale, (TIS) was used to measure turnover intention. Turnover Intention Scale is a three item scale that was measured on a six different response format: "thoughts about quitting my job cross my mind" was measured from strongly disagrees 6-1 to all the time. "I plan to look for a new job within the next 12 months" was measured from strongly disagree 6-1 to strongly agree and "how likely is that, over the next year you will actively look for a new job out of this firm" was measured from very unlikely 6-1 to very likely. O'Driscoll \& Beehr' (1994) found a Cronbach's alpha of .91 for this scale. To make responses easier, a 5-point likert response format was adopted instead of the 7-point that was initially used in the initial study.

For the revalidation of the instrument for the Nigerian sample, it was presented to three experts in the Department of Psychology University of Nigeria Nsukka, for face and content validity. And after that, a pilot study was carried out, using 120 employees from five different banks in Nsukka urban, namely: Zenith Bank Plc, Key Stone Plc, Ogige Micro Finance Bank, Fidelity bank plc and UBA Plc. Out of these 120 questionnaires administered, 99 was correctly responded to, and returned representing $82.5 \%$ return rate. The responses from the pilot study were subjected to item analysis. A cronbach's alpha of .60 was found, and the 3 items were all retained according to Nunnally (1970) that stated that only items with endorsement rates between .02 and .80 are used if all items are measuring the same trait.

\subsection{Perceived Organisational Politics}

Organisational politics scale developed by Kacmar \& Carlson (1997) was used to measure perceived organisational politics. This is a 15 item scale which has three dimensions, including: General Political Behaviour (2 items), Go Along To Get Ahead (7 items), Pay and Policies (16 items). The Cronbach's alpha for General 
Political Behaviour subscale is .77; Go Along to Get Ahead is .78, and Pay and Promotion Policies is .73. The items were measured on a 5-point likert scale ranging from Strongly Agree $=5$, Agree $=4$, Undecided $=3$, Disagree $=2$ and Strongly Disagree $=1$. While some negative items like items: 3, 4,10 and 11, were scored on a reverse direction i.e. 1, 2, 3, 4 and 5. A higher score entail perceptions of higher levels of organizational politics.

For the validation of this scale for the Nigerian samples, it was subjected to face and content validity by three experts in Psychology department, University of Nigeria, Nsukka. After which, a pilot study was carried out using a sample of 120 participants from five different banks in Nsukka urban, namely: Access Bank Plc, Key Stone Plc, Diamond Bank Plc, UBA Plc and Fidelity Bank Plc. Out of this number distributed, 93 copies were properly responded to and returned, representing a $77.5 \%$ return rate. The responses from the pilot study were subjected to item analysis. A Cronbach's alpha of .78 was found, and all the 15 items were retained, according to Nunnally (1970) that stated that only items with endorsement rates between .02 and .80 are used if all items are measuring the same trait.

\subsection{Perceived Organisational Support}

Eisenberger, Huntingtson, Hutchinson, \& Sowa's (1986) Survey of Perceived Organisational Support (SPOS) was used to measure the employees' perception of organisational support. The scale was initially a 36 -item scale that was measured on a seven point likert format $1=$ Strongly Disagree to $7=$ Strongly Agree . Some of the statements were positively worded, i.e. from 1-7, like items 1, 4, 5, 7, $8,10,11,14,15$ and 16 . While others were negatively worded, from 7-1, like items 2, 3, 6, 9, 12 and 13. To make the responses easier, a 5-point likert response format was adopted instead of the 7-point format used initially. Eisenberger et al. (1986) carried out a factor analysis on the scale and 16 items were used as a short form. Eisenberger and his colleagues found a Cronbach's alpha of .97 and item-total correlation ranged from .47 to .83 . For the revalidation of the scale for the Nigerian sample, Onyishi (2006) reported face and content validity. Onyishi also found item-total correlation that ranged .30 to .67; Cronbach's alpha of .88 and a test-retest reliability of .89 .

\subsection{Work Place Incivility}

Tepper's (2000) abusive supervision scale was used to measure supervisor's incivility. The scale has 15 items that were measured on a 6-point likert scale $1=$ Strongly Disagree to 6 = Strongly Agree. Tapper found a Cronbach's alpha of .95. To make the responses easier, a 5-point likert response format was used instead of the 6-point format used initially.

A pilot study was carried out to make the scale suitable for the Nigerian sample, using 120 participants from banks in Nsukka urban. And these banks included: Access Bank, Keystone, Diamond Bank, UBA and Fidelity Bank. Out of 
these 120 copies of questionnaires distributed, 90 copies were properly responded to, and returned representing a 75\% return rate. The responses from the pilot study were subjected to item analysis. A Cronbach's alpha of .79 was found, and all the items were retained according to Nunnally (1970) that stated that only items with endorsement rates between .20 and .80 are used if all items are measuring the same trait.

\subsection{Procedure}

The researcher collected an introductory letter from the Head of department, which was dully signed by the head of the department to enable the management of the banks allow their employees to respond to the questionnaires. After getting approval from the management of each of the ten banks, the researcher was introduced to the customer care staff and after words, three hundred (300) copies of the four (4) instruments were shared among the customer care staff of each of the ten (10) banks selected, who then shared them to their coworkers after their working hours, and then wrote down the names of the employees that were given the questionnaires. After that, the researcher came back the following day and collected the questionnaires from the customer care staff that collected them from their coworkers. In FCMB plc, out of the twenty two (22) questionnaires administered, seventeen (17) copies were properly filled and returned, representing $77.3 \%$ return rate. In First bank plc, out of the thirty five (35) questionnaires administered, twenty five (25) copies were properly filled and returned, representing $71 \%$ return rate. In Eco bank plc, out of the thirty (30) questionnaires administered, twenty one (21) copies were properly responded to, and returned, representing $70 \%$ return rate. In Access bank plc, out of the twenty six (26) questionnaires administered, eighteen (18) copies were properly responded to, and returned, representing 69\% return rate. In Diamond bank plc, out of the thirty (30) questionnaires administered, twenty two (22) copies were properly responded to, and returned, representing $73 \%$ return rate. In UBA plc, out of the thirty two (32) questionnaires administered, twenty eight (28) copies were properly responded to, and returned, representing $87.5 \%$ return rate. In Fidelity bank plc, out of the thirty (30) questionnaires administered, twenty five (25) copies were properly filled and returned, representing $83 \%$ return rate. In Key stone plc, out of the twenty nine (29) questionnaires administered, twenty three (23) copies were properly responded to, and returned, representing $79 \%$ return rate. In GTB plc, out of the thirty two (32) questionnaires administered, twenty four (24) copies were properly responded to, and returned, representing $75 \%$ return rate. In Zenith bank plc, out of the thirty four (34) questionnaires administered, twenty six (26) copies were properly responded to, and returned, representing $76.5 \%$ return rate. In out of the grand total of three hundred (300) questionnaires administered, two hundred and twenty nine (229) copies were properly responded to, and returned, representing $76 \%$ return rate. So the researcher used their responses for analysis. The respondents were assured ano- 
nymity to ensure their fair response.

\subsection{Design/Statistics}

The study employed the cross-sectional survey research design and regression statistics was employed to analyze the data (Table 1).

\section{Results}

The result of the correlation above showed that apart from marital status ( $\mathrm{r}$ $=.08 ; P>.01)$, other control variables are significantly correlated to the criterion variable (turnover intention): Employment status was significantly related to turnover intention $(\mathrm{r}=.20, P<.01)$. Age was significantly related to turnover intention $(\mathrm{r}=.50, P<.001)$. The results above also showed that education was significantly related to turnover intention $(\mathrm{r}=.35, P<.001)$ and organisational tenure was significantly related to turnover intention $(\mathrm{r}=.33, P<.001)$. Job tenure was also significantly related to turnover intention $(\mathrm{r}=.45, P<.001)$.

The results also indicate that all the independent variables are also significantly related to turnover intention. While perceived organistional politics and workplace incivility of supervisor were positively related to turnover intention: Politics $(\mathrm{r}=.38, P<.001)$, incivility $(\mathrm{r}=.18, P<.01)$, perceived organisational support was negatively related to turnover intention $(\mathrm{r}=-.40, P<.001)$. Thus, the higher the perceived politics and workplace incivility, the higher the turnover intention. On the other hand, the higher the perceived support the lower the turnover intention (Table 2).

The result of the regression analyses showed that all the control variables except gender age and job tenure were significantly related to turnover intention.

Table 1. Descriptive statistics and inter-correlations among study variables.

\begin{tabular}{|c|c|c|c|c|c|c|c|c|c|c|c|c|c|}
\hline Variables & mean & SD & 1 & 2 & 3 & 4 & 5 & 6 & 7 & 8 & 9 & 10 & 11 \\
\hline 1) Gende & 1.48 & .50 & & & & & & & & & & & \\
\hline 2) Marital status & 1.35 & .48 & -.04 & & & & & & & & & & \\
\hline 3) Employ status & 1.15 & .36 & $.20^{*}$ & $.13^{*}$ & & & & & & & & & \\
\hline 4) Age & 33.22 & 7.86 & $.50^{\star *}$ & $-.46^{\star *}$ & $-.24^{* *}$ & & & & & & & & \\
\hline 5) Education & 1.20 & .40 & $-.35^{\star *}$ & $.13^{*}$ & -.06 & $-.38^{\star \star}$ & & & & & & & \\
\hline 6) Org'l tenure & 6.09 & 3.6 & $.33^{* *}$ & $-.38^{\star}$ & $-.17^{\star}$ & $.67^{\star *}$ & .03 & & & & & & \\
\hline 7) Job tenure & 3.86 & 3.32 & $.45^{\star *}$ & -.31 & -.09 & $.60^{* *}$ & -.07 & $.75^{\star *}$ & & & & & \\
\hline 8) Politics & 48.97 & 6.32 & $.38^{\star *}$ & -.17 & $-.17^{\star}$ & $.58^{\star \star}$ & -.09 & .48 & $.38^{* *}$ & & & & \\
\hline 9) Support & 57.13 & 11.67 & $-.40^{* *}$ & $-.20^{\star}$ & -.05 & $-.28^{\star *}$ & $.23^{\star *}$ & $-.24^{\star}$ & $-.24^{\star *}$ & $-.41^{\star *}$ & & & \\
\hline 10) Incivility & 48.96 & 10.42 & $.18^{*}$ & .06 & -.09 & $.20^{*}$ & $-.29^{* *}$ & $.25^{* *}$ & $.26^{* *}$ & $.44^{* *}$ & $-.51^{\star *}$ & & \\
\hline 11) Turnover & 11.28 & 2.27 & $.42^{* *}$ & .08 & $.15^{*}$ & $.38^{\star *}$ & $-.34^{* *}$ & $.36^{* *}$ & $.30^{* *}$ & $.50^{* *}$ & $-.84^{* *}$ & $.65^{* *}$ & \\
\hline
\end{tabular}

Key: ${ }^{*}==p<.01 ;{ }^{* *}==p<.001$; Note: A total of 229 bank employees participated in the study. Gender $\mathrm{r}=$ male, $2=$ female); marital statues $(1=$ married, 2 = single); employment status $(1=$ contract, 2 = permanent); education $(1=$ high, $2=$ low $)$ perceived organisational politico, support and workplace incivility high politics, support and workplace incivility. 
Table 2. Hierarchical regression results.

\begin{tabular}{|c|c|c|c|c|}
\hline \multirow{2}{*}{ Variable } & \multicolumn{4}{|c|}{ Step } \\
\hline & 1 & 2 & 3 & 4 \\
\hline Gender & .12 & .04 & -.06 & -.02 \\
\hline Marital status & $.31^{\star *}$ & $.26^{* *}$ & .02 & .01 \\
\hline Employ status & $.17^{\star}$ & $.20^{* *}$ & $.17^{\star \star}$ & $.19^{\star \star}$ \\
\hline Age & .15 & -.07 & -.05 & .09 \\
\hline Education & $-.29^{* *}$ & $-.35^{\star *}$ & $-.21^{\star *}$ & -.12 \\
\hline Organizational tenure & $.43^{\star *}$ & $.36^{* *}$ & $.23^{\star *}$ & $-.02^{*}$ \\
\hline Job tenure & -.08 & -.03 & -.06 & .07 \\
\hline Perceived politics & & $.41^{* *}$ & $.19^{* *}$ & -.09 \\
\hline Perceived support & & & $-.69^{* *}$ & $.61^{\star *}$ \\
\hline Workplace incivility & & & & $.25^{\star *}$ \\
\hline $\mathrm{R}$ square & .37 & .47 & .79 & .82 \\
\hline R square change & .39 & .10 & .31 & .03 \\
\hline F change & 19.87 & 42.91 & 338.45 & 39.43 \\
\hline$F$ value & 19.87 & 26.04 & 96.26 & 105.78 \\
\hline
\end{tabular}

Key: ${ }^{*}=p<.01{ }^{* *}=p<.001$.

Marital status ( $\beta=31, p<.001)$; Employment status $(\beta=.17, p<.01)$; Education $(\beta=-.29, p<.001)$; organizational tenure $(\beta=.43, p<.001)$. However, the control variables accounted for $36.7 \%$ of the variance in turnover intention of employees.

The results of the analyses equally revealed that perceived organizational politics significantly and positively related to turnover intention $(\beta=.41, p<.001)$. Thus, the first hypothesis is confirmed. Perceived politics accounted for $46.8 \%$ of the variance in turnover intention, above and beyond the control variables. Perceived organizational support is negatively related to turnover intention $(\beta=$ $-.69, p<.001)$, and accounted for $79.0 \%$ of the variance in turnover intention above and beyond that of the control variables and perceived organizational politics. This result upholds the second hypothesis which stated that perceived organizational support will be negatively related to turnover intention.

The results of the analyses equally indicated that workplace incivility significantly predicted turnover intention among employees $(\beta=.25, p<.001)$. It explained $82.1 \%$ of the variance in turnover intention above and beyond the control variables, perceived organizational politics, and perceived organizational support. This result implies that the third hypothesis that workplace incivility of supervisions will not significantly predict turnover intention is rejected.

\section{Discussion}

The results of the regression analysis revealed that perceived organizational poli- 
tics significantly and positively related to turnover intention $(\mathrm{r}=.41, p<.001)$. Perceived organisational politics accounted for $46.8 \%$ of the variance in turnover intention above and beyond control variables. Thus the first hypothesis which states that perceived organizational politics will not significantly predict intention for quit was not confirmed. This finding is consistent. With that of Vigoda (2000), who found positive relationship between perceived organizational politics and turnover intention among employees and supervisors in the north Isreal. Thus, employees who perceived a high level of politics in their work place reported higher levels of turnover intention than did employees who perceive a low level of politics. Further, this finding supports Cropanzano, Howes, Grandy, \& Toth (1997) who found a positive relationship between perceived organizational politics. The present finding portrays perceived organizational politics as a strong factor in relation to employees' turnover intention their organizations. Though organisational politics may be beneficial to some individuals in the organisation, it has been implicated to be the cause of some of the negative job out comes, more especially turnover intention.

The second hypothesis which stated that perceived organisational support will be negatively related to turnover intention was supported because the regression analysis indicated that perceived organization support is negatively related to turnover intention $(\mathrm{r}=-.69, p<.001)$. This finding is consistent with that of Hui, Teo, \& Lee (2007) that examined both perceived organisational support and turnover intention and found perceived organizational support was negatively related to thoughts of quitting the organizational. This finding also supported that of Kinnunen, Feldt, \& Makikangas (2008), who found that perceived organizational politics was negatively related to likelihood of leaving an organization and the frequency of thoughts about quitting the organization.

The consistency in the above-mentioned findings imply that employees who feel that their organization values their contribution and cares about their well-being will be less likely to have thoughts about quitting their jobs. This finding also concur with some other findings linking perceived organizational support and turnover intention like Eisenberger et al. (2001) and Allen et al. (2003). On the contrary, this finding contradicts that of Lew (2009) who found that perceived organizational support has an insignificant direct effect on employees' turnover intention. The researcher believes that reason for this inconsistency might be because in Lew (2009) the influence of perceived organizational support on turnover intention is only through the indirect effect via affective organizational commitment. Otherwise it is expected that employee who perceives organizational support should be less likely to have intention of quitting the organizational. In line with social exchange theory (Blau, 1964), the study result indicates that an employee who believes that his organization does not care about his or her well-being has a higher tendency to want to leave and seek employment in more rewarding organizations. On the other hand, and employee who feels that the organization values his contributions and cares about his 
well-being will be more likely to want to maintain membership in the organization. Therefore it would be beneficial for organizations which want to keep their employees to implement strategies that enhance perceived organizational support by creating a positive working environment.

The third hypothesis which stated that work place incivility of supervisor will not predict turnover intention was rejected. And this finding concurs with that of Pearson \& Porath (2005) who found that some employees thought about quitting their organization as the only solution to experience of incivility they face in the organization. This finding is also in consistence with those of Pearson (1999), Shim \& Chang (2011) who found positive relationships between workplace incivility of supervisor and intention to quit the organization. There are several managerial implications of the findings. The reduce turnover intentions, which sometimes turn into actual turnover, managers are encouraged to right incivility in their. Various organizations, as this finding has agreed with a whole lots of findings in pinpointing this negative impact of incivility in the workplace.

\section{Implications of the Findings}

Given the considerable implications that turnover intention have for performance and commitment, better understanding of its antecedents is important. One way to arrive at this understanding is to explore relevant antecedents that have not be collectively linked to turnover intention, especially in Africa as the present researcher has done with perceived organizational politics, support and workplace incivility of supervisor on turnover intention. The researcher tried to support the idea that these independent variables should be considered prominent phenomena with significant consequences on employees' intention to quit the organization.

This present research found supportive evidence providing the positive relationship between perceived organization politics and turnover intention; negative relationship between perceived organizational support and turnover intention and workplace incivility and turnover intention. These results have important implications for management practices and development; therefore managers should endevour to set up organisational systems that will inhibit the destructive impact of organizational politics and workplace incivility and subsequently enhance polices that support the welfare and interest of the employees to reduce their turnover intention to below five percent.

\section{Conclusion}

The study investigated perceived organisational politics, support and workplace place incivility of supervisor as predictors of intention to quit the organisation. Some theories and models of turnover intention were reviewed and the empirical studies indicated that turnover intention has not been much researched on, in the African context unlike what it is in the Western world. Three hypotheses 
were tested: perceived organisational politics will not significantly predict turnover intention, perceived organisational support will be negatively related to turnover intention and workplace incivility of supervisor will not predict intent to quit. And these showed that bankers who perceive politics in their organisation had the intention to Quit their organisation; on the other side, those who perceive their organisation to be supportive had no intention to quit, while those who experienced work place incivility of supervisor had the intention to quit their organization.

Therefore, this research has contributed to empirical evidence confirming the assumption that perceived organisational politics, support and workplace incivility of supervisor predict turnover intention. The findings on the significant effects of perceived organisational politics, support and workplace incivility on turnover intention demonstrate the need for organisations to provide adequate measures to checkmate organizational politics; workplace incivility and encourage support to their employees. The need for the above mentioned measures anchors in the fact that when the turnover intention rate is high, the actual turnover will be higher, and consequently, the organisations will incur major costs in recruiting and training the new intakes in the organisations.

\section{Conflicts of Interest}

The authors declare no conflicts of interest regarding the publication of this paper.

\section{References}

Allen, D. G., shore, L. M., \& Griffeth, R. W. (2003). The Role of Perceived Organisational Support and Supportive Human Resource Practices in the Turnover Process. Journal of Management, 29, 99-118. https://doi.org/10.1177/014920630302900107

Andersson, L. M., \& Pearson, C. M. (1999). Tit for Tat? The Spiralling Effect of Incivility in the Workplace. Academy of Management Review, 24, 252-271. https://doi.org/10.5465/amr.1999.2202131

Aselage, J., \& Eisenberger, R. (2003). Perceived Organisational Support and Psychological Contracts: A Theoretical Integration. Journal of Organisational Behaviour, 24, 491-509. https://doi.org/10.1002/job.211

Baron, R. A., \& Neuman, J. H. (1996). Workplace Violence and Workplace Aggression: Evidence on Their Relative Frequency and Potential Causes. Aggressive Behaviour, 25, 161-173. https://doi.org/10.1002/(SICI)1098-2337(1996)22:3<161::AID-AB1>3.0.CO;2-Q

Baron, R. A., \& Neuman, J. H. (1998). Workplace Aggression the Ice Berg beneath the Tip of Workplace Violence: Evidence on Its Forms, Frequency and Targets. Public Administration Quarterly, 21, 446-464.

Blau, P. M. (1964). Exchange and Power in Social Life. New York: Wiley.

Bozeman, D. P., Perrwe, P. L., Hochwarter, W. A., \& Brymer, R. A. (2001). Organisational Politics, Perceived Control, and Work Outcomes: Boundary Conditions on the Effects of Politics. Journal of Applied Social Psychology, 31, 486-503.

https://doi.org/10.1111/j.1559-1816.2001.tb02052.x

Cropanzano, R., Howes, J. C., Grandey, A. A., \& Toth, P. (1997). The Relationship of Or- 
ganisational Politics and Support to Work Behaviours, Attitudes, and Stress. Journal of Organisational Behaviour, 18, 159-180.

https://doi.org/10.1002/(SICI)1099-1379(199703)18:2<159::AID-JOB795>3.0.CO;2-D

Djurkovic, N., McCormack, D., \& Casimir, G. (2004). The Physical and Psychological Effects of Workplace Bullying and Their Relationship to Intention to Leave: A Test of the Psycholomatic and Disability Hypotheses. International Journal of Organisational Theory and Behaviour, 7, 469-497. https://doi.org/10.1108/IJOTB-07-04-2004-B001

Eisenberger, R., Armchi, S., Rexwinkel, B., Lynch, P. D., \& Rhoades, L. (2001). Reciprocation of Perceived Organisational Support. Journal of Applied Psychology, 86, 42-51. https://doi.org/10.1037/0021-9010.86.1.42

Eisenberger, R., Cummings, J., Armeli, S., \& Lynch, P. (1997). Perceived Organisational Support, Discretionary Treatment, and Job Satisfaction. Journal of Applied Psychology, 82, 812-820. https://doi.org/10.1037/0021-9010.82.5.812

Eisenberger, R., Fasola, P., \& Davis-Lamastro, V. (1990). Perceived Organisational Support, Employee Diligency, Commitment, and Innovation. Journal of Applied Psychology, 75, 51-59. https://doi.org/10.1037/0021-9010.75.1.51

Eisenberger, R., Fasolo, P., \& Davis-Lamastro, V. (1990). Perceived Organisational Support, Employee Diligence, Commitment and Innovation. Journal of Applied Psychology, 75, 51-59. https://doi.org/10.1037/0021-9010.75.1.51

Eisenberger, R., Huntington, R., Hutchison, S. O., \& Sowa, D. (1986). Perceived Organisational Support. Journal of Applied Psychology, 71, 500-507. https://doi.org/10.1037/0021-9010.71.3.500

Eisenberger, R., Rhoades, L., \& Cameron, J. (1999). Does Pay for Performance Increase or Decrease Perceived Self-Determination and Intrinsic Motivation? Journal of Personality and Social Psychology, 77, 1026-1040. https://doi.org/10.1037/0022-3514.77.5.1026

Harris, K. J., Andrews, M. C., \& KacMar, K. M. (2007). The Moderating Effects of Justice on the Relationship between Organisational Politics and Work Place Attitudes. Journal of Business and Psychology, 22, 135-144. https://doi.org/10.1007/s10869-007-9054-9

Hochwarter, W. A., Kacmar, C., Perrewe, P. L., \& Johnson, D. (2003). Perceive Organisational Support as a Mediator of the Relationship between Politics Perceptions and Work Outcomes. Journal of Vocational Behaviour, 63, 438-456. https://doi.org/10.1016/S0001-8791(02)00048-9

Hom, P. W., \& Griffeth, R. W. (1995). Employee Turnover. Cincinnati, OH: South-Western Publishing.

Hui, K. L., Ten, H. H., \& Lee, S. Y. T. (2007). The Value of Privacy Assurance: An Exploratory Field Experiment. MIS Quarterly, 31, 19-33. https://doi.org/10.2307/25148779

Kacmar, K. M., \& Baron, R. A. (1999). Organisational Politics: The State of the Field Links to Related Processes and an Agenda for Future Research. In K. M. Rowland, \& G. R. Ferris (Eds.), Research in Personnel and Human Resources Management (pp. 101-139). Stanford, CA: T:JA Press.

Kacmar, K. M., \& Carlson, D. S. (1997). Further Validation of the Perceptions of Organisational Politics Scale (pops): A Multiple Sample Investigation. Journal of Management, 23, 627-658. https://doi.org/10.1177/014920639702300502

KacMar, K. M., Bozeman, D. P., Carlson, D. S., \& Anthony, W. P. (1999). An Examination of the Perceptions of Organisational Politics Model: Replication and Extension. Human Relations, 52, 383-416. https://doi.org/10.1177/001872679905200305

Kinnunen, U., Feldt, T., \& Makikangas, A. (2008). Testing the Effort-Reward Balance among Finnish Managers: The Role of Perceived Organizational Support. Journal of 
Occupational Health, 13, 114-127. https://doi.org/10.1037/1076-8998.13.2.114

Lew, T. (2009). The Relationship between Perceived Organisational Support, Felt Obligation, Affective Organisational Commitment and Turnover Intention of Academics Working with Private Higher Education Institutions in Malaysia. European Journal of Social Sciences, 9, 72-87.

March, J. G., \& Simon, H. A. (1958). Organisations. New York, NY: Wiley.

Nunnally, J. C. Jr. (1970). Introduction to Psychological Measurement. New York, NY: McGraw-Hill.

O’Driscoll, M. P., \& Beehr, T. A. (1994). Supervisor Behaviors, Role Stressors and Uncertainty as Predictors of Personal Outcomes for Subordinates. Journal of Organisational Behaviour, 15, 141-154. https://doi.org/10.1002/job.4030150204

Onyishi, I. E. (2006). The Relationship between Perceived Organisational Support and Organisational Citizenship Behaviour. Nigerian Journal of Psychological Research, 5, 37-51.

Pearson, C. M., \& Porath, C. L. (2005). On the Nature, Consequences, and Remedies of Workplace Incivility: No Time for "Nice"? Think Again. Academy of Management EXecutive, 19, 7-18. https://doi.org/10.5465/ame.2005.15841946

Pfeffer, J. (1992). Management with Power. Boston, MA: Harvard Business School Press.

Rhoades, L., \& Eisenberger, R. (2002). Perceived Organisational Support: A Review of the Literature. Journal of Applied Psychology, 87, 698-714. https://doi.org/10.1037/0021-9010.87.4.698

Settoon, R. P., Bennet, N., \& Liden, R. C. (1996). Social Exchange in Organisations: Perceived Organisational Support, Leader-Member Exchange, and Employee Reciprocity. Journal of Applied Psychology, 81, 219-227. https://doi.org/10.1037/0021-9010.81.3.219

Shanock, L. R., \& Eisenberger, R. (2006). When Supervisors Feel Supported: Relationships with Subordinates' Perceived Supervisor Support, Perceived Organisational Support and Performance. Journal of Applied Psychology, 91, 689-695.

https://doi.org/10.1037/0021-9010.91.3.689

Shim, J., \& Chang, H. J. (2011). The Relationship between Workplace Incivility and the Intention to Leave; Implication to HRD (pp. 674-679). ICERI 2011 Proceedings.

Shore, L. M., \& Shore, T. H. (1995). Perceived Organisational Support and Organisational Justice. In R. S. Cropanzano, \& K. M. Kacmar (Eds.), Organisational Politics, Justice, and Support: Managing the Social Climate of the Workplace (pp. 149-164). Westport, CT: Quorum.

Shore, L. M., \& Tetrick, L. E. (1991). A Construct Validity Study of the Survey of Perceived Organisational Support. Journal of Applied Psychology, 76, 637-643. https://doi.org/10.1037/0021-9010.76.5.637

Tepper, B. J. (2000). Consequences of Abusive Supervision. Academy of Management Journal, 43, 178-190.

Vigoda, E. (2000). Internal Politics in Public Administration Systems: An Empirical Examination of Its Relationship with Job Congruence, Organisational Citizenship Hehaviour, and In-Role Performance. Personnel Management, 29, 185-210. https://doi.org/10.1177/009102600002900203

Zapf, D., Knorz, C., \& Kulla, M. (1996). On the Relationship between Mobbing Factors, and Job Content, Social Work Environment, and Health Outcomes. European Journal of Work and Organisational Psychology, 5, 215-237.

https://doi.org/10.1080/13594329608414856 